\section{1) $\mathbf{N}$ I

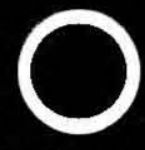 \\ a}

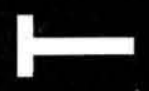

$\boldsymbol{\alpha}$

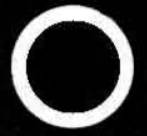

Q

LI

$\boldsymbol{\alpha}$

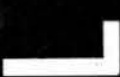

1

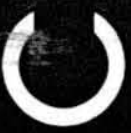

UI

Q

( )
Freeze-Thaw Tests of

Full-Scale Roller-Compacted Concrete Test Sections

Edel R. Cortez and Robert A. Eaton

July 1990 


\section{Special Report 90-25}

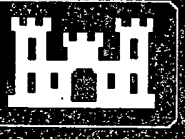

U.S. Army Corps

of Engineers

Cold Regions Research \& Engineering Laboratory

\section{Freeze-Thaw Tests of \\ Full-Scale Roller-Compacted Concrete Test Sections}

Edel R. Cortez and Robert A. Eaton 


\section{PREFACE}

This report was prepared by Edel R. Cortez, Civil Engineer, and Robert A. Eaton, Research Civil Engineer, Experimental Engineering Division, CRREL. Funding was provided by the Office of the Chief of Engineers under FY85-89 Facilities Investigation Studies Program, Work Unit 101, Monitor Roller-Compacted Concrete in Freeze/Thaw Areas.

The authors thank the following persons for supporting the program: William Quinn and Carlisle Gardner of CRREL; David Pittman, Steve Ragan, Paul Hadala, Bryant Mather, Ron Hutchinson, Walter Barker, Harry Ulery, Ray Rollings and Don Ladd of the U.S. Army Waterways Experiment Station; Oswin Keifer, Jr., of the North Pacific Division, Corps of Engineers; Joe Lamond and Edwin Dudka of the Office of the Chief of Engineers; and Dieter Rommel and Al Ezzy of Jack Cewe, Ltd. The authors also appreciate the assistance of CRREL's Refrigeration Department and Soils Laboratory. Charles Korhonen of CRREL is also acknowledged for his valuable input.

The contents of this report are not to be used for advertising or promotional purposes. $\mathrm{Ci}$ tation of brand names does not constitute an official endorsement or approval of the use of such commercial products. 


\section{CONTENTS}

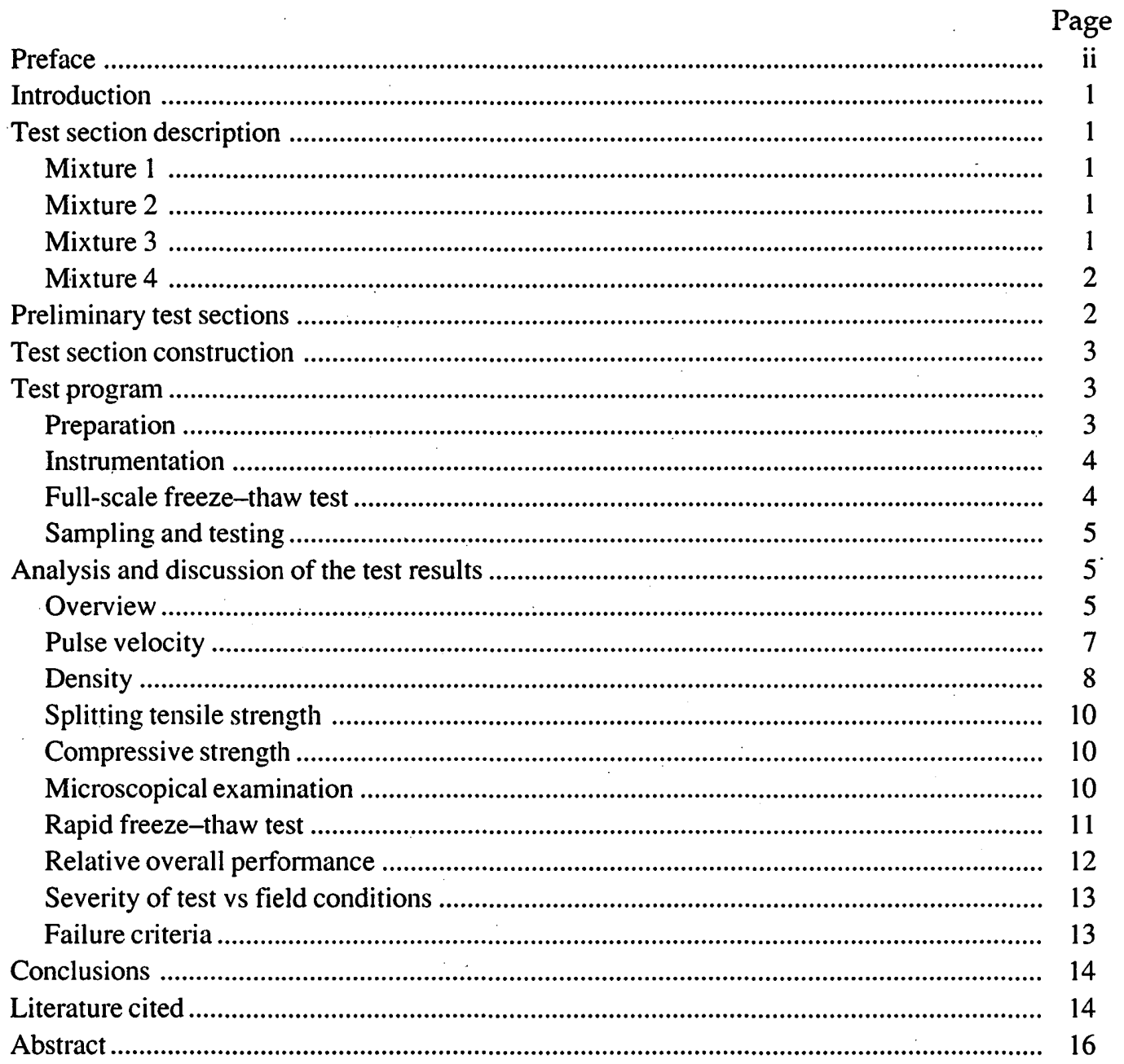

\section{ILLUSTRATIONS}

\section{Figure}

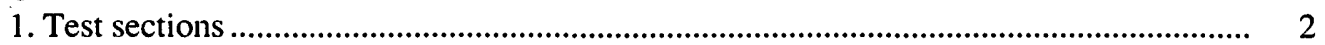

2. Typical set of thermocouples ............................................................................................. 4

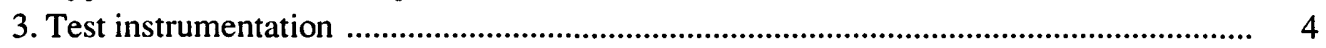

4. Temperature of the slab during 90 hours ......................................................................... 5

5. Generation of hydraulic pressure in cement paste ........................................................... 6

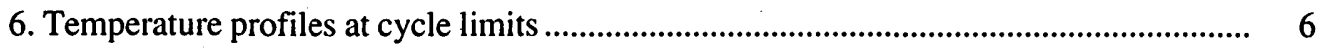

7. Peak temperature profile ............................................................................................. 7

8. Pulse velocity results of the RCC CRREL test ............................................................. 8

9. Effect of aging on the compressive strength ............................................................ 9

10. Density results of the RCC CRREL test ................................................................... 9

11. Splitting tensile strength results of the RCC CRREL test ................................................ 10 


\title{
Freeze-Thaw Tests of Full-Scale Roller-Compacted Concrete Test Sections
}

\author{
EDEL R. CORTEZ AND ROBERT A. EATON
}

\section{INTRODUCTION}

Roller-compacted concrete (RCC) is a construction technology that combines the features of cement-treated aggregate base, portland cement concrete and asphalt pavements to produce a low-cost pavement material.

In 1975 the U.S. Army Corps of Engineers Waterways Experiment Station (WES) constructed an experimental RCC test section at Vicksburg, Mississippi. This experiment provided the Corps with the preliminary construction experience using this technology and a basis for further experiments. RCC was initially used on a commercial basis in British Columbia, Canada, in 1976, and RCC acceptance is growing rapidly (Gillespie 1989). However, preliminary tests run on samples from early projects revealed susceptibility to cycles of freezing and thawing (White 1986).

CRREL is conducting a research program on the durability of RCC with respect to its freeze-thaw resistance. In November 1984, eight test sections were built inside a controlled-environment building (the ATCO building) at CRREL in Hanover, New Hampshire (Gardner and Eaton 1984). Four concrete mixtures with two drainage conditions were used.

\section{TEST SECTION DESCRIPTION}

Figure 1 shows the test sections. The test sections are designated by a number for the concrete mixture (Table 1) and a letter for the drainage condition. A vertical layer of insulation separates lane A from lane B. Lane B represents a "typical" good field drainage condition. Lane A represents a "natural" field high water table simulated by an impervious vinyl membrane located $15.2 \mathrm{~cm}(6$ in.) below the bottom of the slab.

\section{Mixture 1 (test sections 1A and 1B)}

Mix 1 contains a natural, coarse, unwashed ("dirty") aggregate with a maximum size of $19 \mathrm{~mm}(0.75 \mathrm{in}$.). Type II portland cement was used at a rate of $334.6 \mathrm{~kg}$ / $\mathrm{m}^{3}\left(564 \mathrm{lb} / \mathrm{yd}^{3}\right)$, with a 0.37 water-cement ratio. No admixture was used. This mix design was suggested by consultants from Jack Cewe, Ltd. based on their previously successful field projects.

\section{Mixture 2 (test sections 2A and 2B)}

Mix 2 contains a crushed, coarse, angular limestone aggregate with a maximum size of $19 \mathrm{~mm}(0.75 \mathrm{in}$.) and a natural fine aggregate. Type II portland cement was used at a rate of $336.4 \mathrm{~kg} / \mathrm{m}^{3}\left(567 \mathrm{lb} / \mathrm{yd}^{3}\right)$, with a 0.35 water-cement ratio. A vinsol resin of the trademark Daravair was added to the mixture as an air-entraining agent (AEA). The manufacturer specified the dosage of AEA to be from 0.75 to 3 fluid ounces for each 94-lb sack of cement ( $0.5-2$ gm of AEA $/ \mathrm{kg}$ of cement) to generate $4-8 \%$ of entrained air. Due to previous unsatisfactory results with conventional dosages, we decided to try a dosage 2.2 times the maximum specified dosage. The actual dosage was $4.4 \mathrm{gm}$ of AEA/kg of portland cement, equivalent to $7.04 \mathrm{oz}$ of AEA for each $100 \mathrm{lb}$ of portland cement. Mixtures 2 and 3 were suggested by WES. They were designed for a 28-day compressive strength of at least $20.7 \mathrm{MPa}$ (3000 psi).

Mixture 3 (test sections 3A and 3B)

This is the same as mixture 2, except that no AEA was added.

Table 1. Test sections mix design.

\begin{tabular}{ccccccc}
$\begin{array}{c}\text { Test } \\
\text { section }\end{array}$ & $\begin{array}{c}\text { Marsize } \\
\text { aggregate } \\
(\mathrm{mm})\end{array}$ & $\begin{array}{c}\text { Aggregate } \\
\text { type }\end{array}$ & $\begin{array}{c}\text { Portland } \\
\text { centent } \\
(\mathrm{kg})\end{array}$ & $\begin{array}{c}\text { Water-cement } \\
\text { ratio }\end{array}$ & $\begin{array}{c}\text { AEA } \\
\text { Slump } \\
(\mathrm{cm})\end{array}$ \\
\hline & 19 & natural & 334.6 & 0.37 & No & 0 \\
1 & 19 & crushed & 336.4 & 0.35 & Yes & 0 \\
2 & 19 & crushed & 336.4 & 0.35 & No & 0 \\
3 & 19 & crushed & 334.6 & 0.70 & Yes & 12.7 \\
4 & 19 & con
\end{tabular}




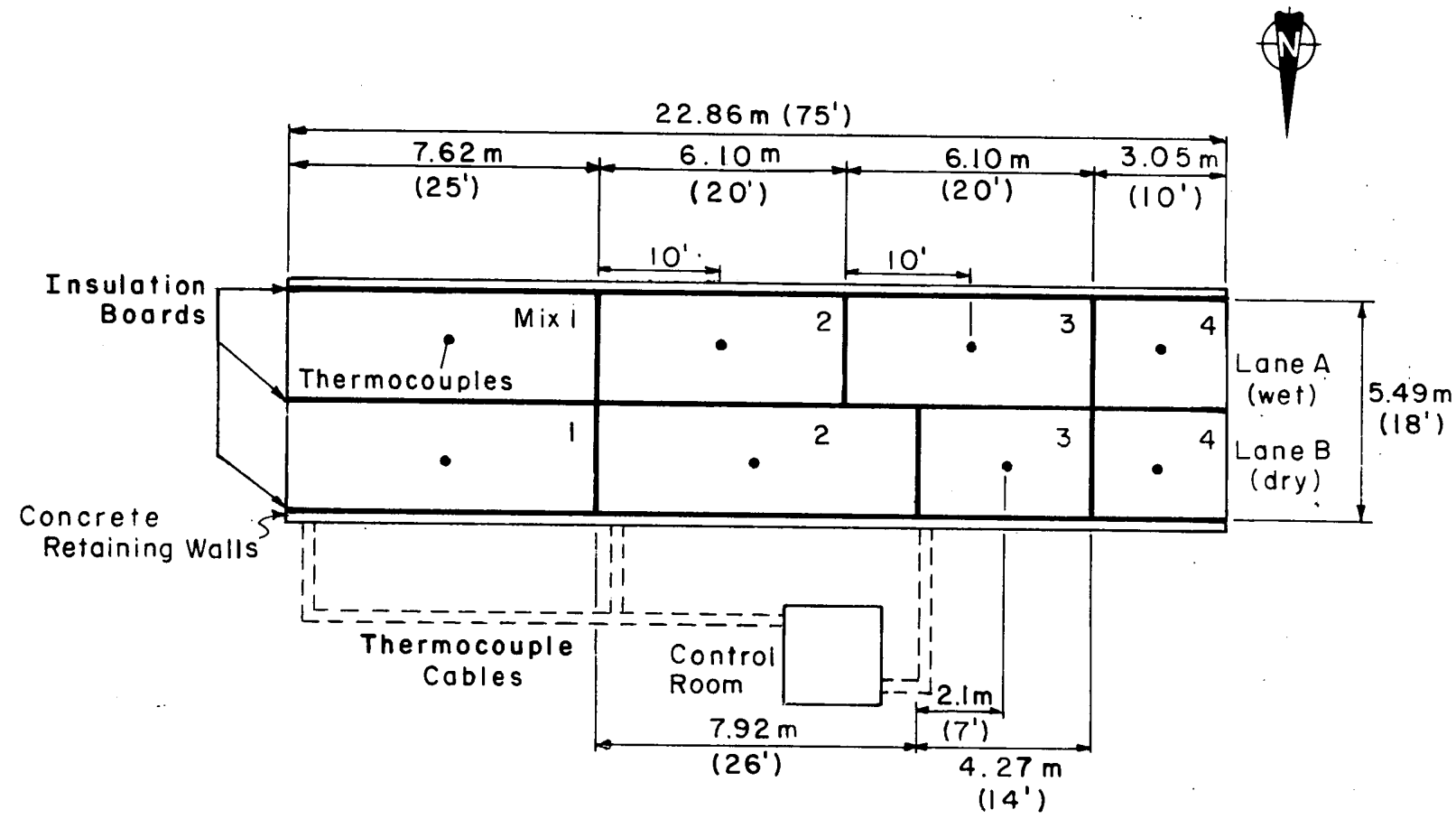

a. Plan view.

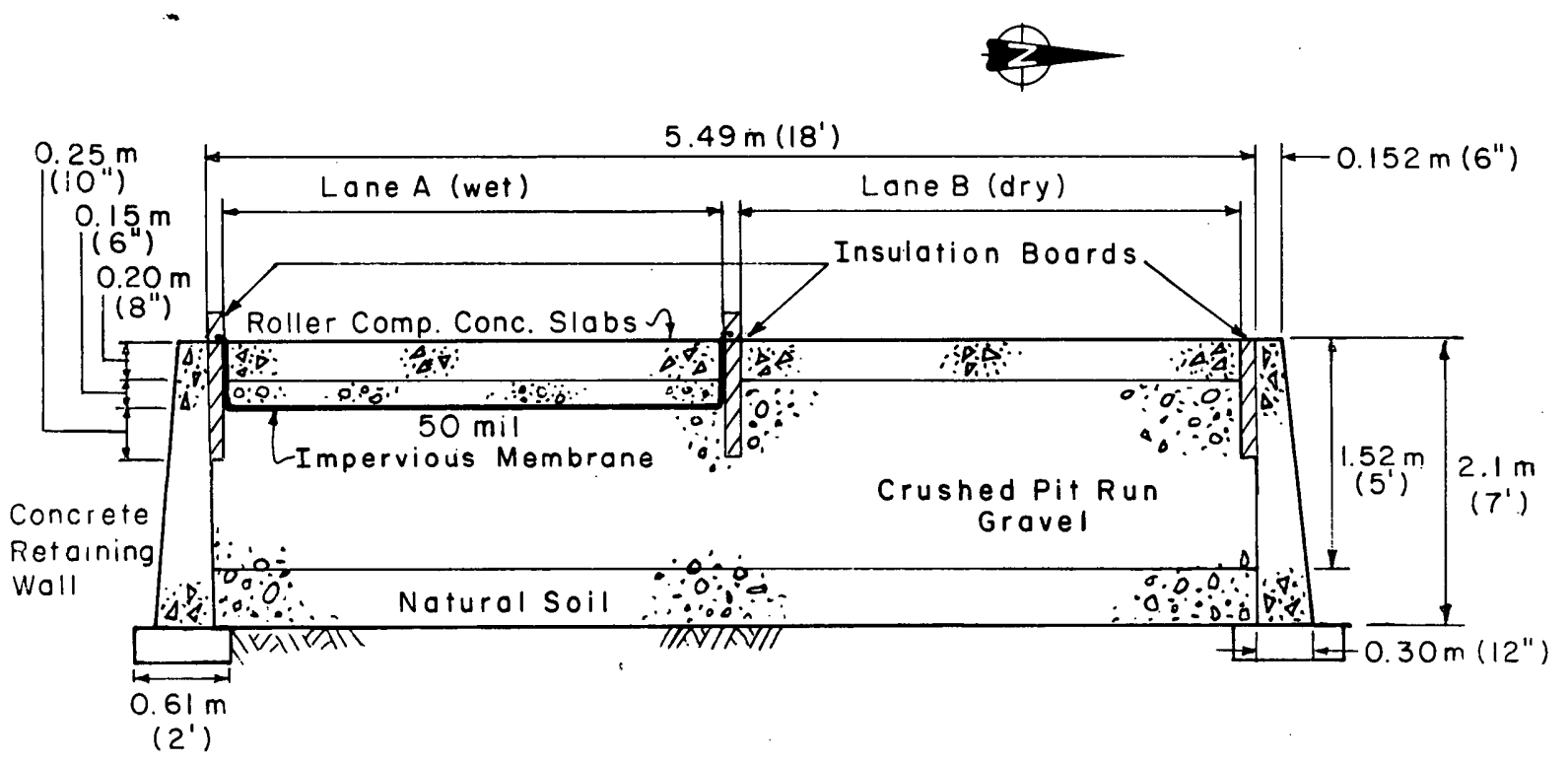

Figure 1. Test sections.

\section{Mixture 4 (test sections 4A and 4B)}

This mixture was a ready-mixed portland cement concrete (PCC) with a slump of $12.7 \mathrm{~cm}$ (5 in.) and no reinforcement or joints. AEA at a rate of $1.33 \mathrm{gm} / \mathrm{kg}$ of cement ( 2 oz for each 94 -lb sack of cement) was added to produce 5\% entrained air. Mixture 4 was used for baseline comparison only and was subjected to the same test conditions as the rest of the mixtures.

All the mixtures used local aggregates that have satisfactory performance records. They were not tested for soundness, abrasion, specific gravity or absorption. No fly ash, silica fume, retarders or other admixtures (except the AEA in mixes 2 and 4 ) were used.

\section{PRELIMINARY TEST SECTIONS :}

Prior to the construction of the test sections inside the ATCO building, three preliminary test sections were built outdoors. They were constructed to test the system so that the test sections inside the ATCO building would 
be properly constructed. Thermocouples were embedded at the top and bottom of two test slabs to monitor the temperatures during curing. AEA at a rate of $2.2 \mathrm{gm} / \mathrm{kg}$ of portland cement (1.1 times the maximum dosage prescribed by the manufacturer), equivalent to $3.52 \mathrm{oz}$ for each $100 \mathrm{lb}$ of portland cement, was added to the mixture. One of the three test sections was covered with wet burlap and a $0.15-\mathrm{mm}$ plastic sheet. The other two test sections were left uncovered. The air temperature during the first two days reached a minimum of $-2^{\circ} \mathrm{C}$ $\left(28^{\circ} \mathrm{F}\right)$ and a maximum of $10^{\circ} \mathrm{C}\left(50^{\circ} \mathrm{F}\right)$.

This preliminary experiment led to the following conclusions:

- The initial aggregate with a maximum size of $3.8 \mathrm{~cm}$ (1.5 in.) caused segregation and low surface quality. Therefore, an aggregate with a maximum size of 1.9 $\mathrm{cm}(0.75 \mathrm{in}$.) was specified.

- The AEA at the initial specified dosage did not generate the desired air void system, as revealed by measurements on the fresh concrete. Therefore, we decided to double the dose.

- The burlap and plastic sheet system effectively kept the temperatures in the RCC test slab between $14^{\circ} \mathrm{C}$ $\left(57^{\circ} \mathrm{F}\right)$ and $22^{\circ} \mathrm{C}\left(72^{\circ} \mathrm{F}\right)$. The uncovered test sections reached a minimum of $7^{\circ} \mathrm{C}\left(45^{\circ} \mathrm{F}\right)$ and a maximum of $26^{\circ} \mathrm{C}\left(79^{\circ} \mathrm{F}\right)$.

\section{TEST SECTION CONSTRUCTION}

Two days after the preliminary test sections were built outside, the main test sections were constructed inside the ATCO building. Test sections 1A, 1B, 2A, 2B, 3A and 3B were constructed on 29 November 1984 . Test sections 4A and 4B were placed the following day.

A Barber Greene asphalt cold-mix plant equipped with a stationary twin-shaft pug-mill mixer was used for the RCC mixtures. The plant was located $11 \mathrm{~km} \mathrm{(7}$ miles) away from the construction site. This plant has a batch capacity of $907 \mathrm{~kg}(2000 \mathrm{lb})$.

For mixtures 1 and 3 the charging sequence was as follows: aggregate (by weight), water (by pails) and cement (by sacks). The total mixing time was $45 \mathrm{sec}$ onds. For mixture 2 the charging sequence and mixing time was the same as for mixtures 1 and 3, except that the AEA was premixed with the water. Three dump trucks hauled the fresh RCC from the mix plant to the construction site.

Test sections $1 \mathrm{~A}$ and $1 \mathrm{~B}$ were first constructed at the east end of the building, and the other test sections followed in numerical order. The building's ambient temperature was artificially kept at approximately $16^{\circ} \mathrm{C}$ $\left(61^{\circ} \mathrm{F}\right)$ during the construction and curing.

A 1.32-m-thick (52-in.) gravelly base was placed and compacted. Because of the considerable base thickness, the effect of the subgrade material on the RCC pavement was negligible. A rubber-tired asphalt paver was used to place the RCC in a single $22.5-\mathrm{cm}$ (9-in.) uncompacted layer. Its vibrating screed was not used.

A few minutes after the material was placed, a 20ton, double-steel-drum vibratory roller passed over the mix four times in the vibratory mode and one time in the static mode. The roller was set at low frequency and long amplitude during the initial two passes and at high frequency and short amplitude during the third and fourth passes. The small hairline cracks that developed at the surface could not be sealed. Current specifications require that a rubber-tired roller be used to seal those cracks, but no rubber-tired roller was available.

The test sections were moistened immediately after the rolling operations; they were covered with burlap and kept moist around the clock for 14 days.

When these test sections were built, there were no defined quality control procedures for RCC pavements. The quality control was therefore limited to the slump test and close supervision of the construction operations.

\section{TEST PROGRAM}

\section{Preparation}

Table 2 lists the samples taken from each test section soon after the 14-day curing period. The slab.samples were sent to the Waterways Experiment Station (WES) in Vicksburg, Mississippi, for test and comparison with other RCC projects. The beams and cores were tested at CRREL.

The density, compressive strength, flexural strength and static modulus of elasticity at 40 days of age, and be-

Table 2. Initial sampling and testing of each section.

\begin{tabular}{clll} 
Quantity & \multicolumn{1}{c}{ Sample } & \multicolumn{1}{c}{ Test } & \multicolumn{1}{c}{$\begin{array}{c}\text { ASTM } \\
\text { designation }\end{array}$} \\
\hline & & & \\
1 & $76 \times 76 \times 20 \mathrm{~cm}(30 \times 30 \times 8 \mathrm{in}$.$) slab$ & rapid freeze-thaw test & C-666 \\
3 & $15 \times 15 \times 60 \mathrm{~cm}(6 \times 6 \times 24$ in. $)$ beams & flexural strength & C-293 \\
1 & $10 \mathrm{~cm}$ diam $\times 20 \mathrm{~cm}(4$ in. diam $\times 8$ in. $)$ core & microscopical examination & C-457 \\
1 & $10 \mathrm{~cm}$ diam $\times 20 \mathrm{~cm}(4$ in. diam $\times 8$ in. $)$ core & pulse velocity and & C-597 \\
& & splitting tensile strength & C-496 \\
1 & $10 \mathrm{~cm}$ diam $\times 20 \mathrm{~cm}(4$ in. diam $\times 8$ in. $)$ core & density and compressive strength & C-39 \\
\hline
\end{tabular}


Table 3. Average test results with no freeze-thaw cycles at $\mathbf{4 0}$ days of age.

\begin{tabular}{ccccc} 
Sample & $\begin{array}{c}\text { Density } \\
\left(\mathrm{kg} / \mathrm{mt}^{3}\right)\end{array}$ & $\begin{array}{c}\text { Compressive } \\
\text { strength } \\
(M P a)\end{array}$ & $\begin{array}{c}\text { Modulus of } \\
\text { elasticity } \\
(\mathrm{GPa})\end{array}$ & $\begin{array}{c}\text { Flexural } \\
\text { strength } \\
(M P())\end{array}$ \\
\hline 1A & - & - & - & - \\
1B & 2269 & 26.62 & 10.79 & 5.17 \\
2A & 2441 & 34.63 & 19.21 & - \\
2B & 2439 & 38.91 & 22.57 & 7.18 \\
3A & 2366 & 25.64 & 18.00 & - \\
3B & 2347 & 27.41 & 13.84 & 5.75 \\
4A & - & - & - & - \\
4B & 2339 & 35.70 & 16.29 & 5.40 \\
\hline
\end{tabular}

fore any freeze-thaw cycles were applied, are presented in Table 3. These were tested at CRREL.

\section{Instrumentation}

During construction, one set of copper-constantan thermocouples was embedded at the center of each of the test sections. Each set is composed of 12 thermocouples. Figure 2 illustrates the distribution of a typical set of thermocouples through the RCC slab and the top portion of the base course.

The thermocouple cables were connected to an electronic data logger located in a control room at the side of the test sections. Temperature readings were recorded at two-hour intervals.

An industrial refrigeration unit and an oil furnace provided the heat transfer from and to the test sections by means of freezing/thawing panels. A 0.61 -m-thick (2-ft) fiberglass insulation layer was placed on top of the panels. Figure 3 illustrates the main components of the equipment.

\section{Full-scale freeze-thaw tests}

After the curing and initial sampling, the sections in test lane A were ponded with $7.6 \mathrm{~cm}$ ( $3 \mathrm{in}$.) of water for three days. The water was removed and the surface swept but left wet. The freezing/thawing panels and insulation were installed and the freeze-thaw cycling began 40 days after construction.

The target limits for a typical freeze-thaw cycle were $-6.7^{\circ} \mathrm{C}\left(20^{\circ} \mathrm{F}\right)$ and $1.7^{\circ} \mathrm{C}\left(35^{\circ} \mathrm{F}\right)$ at the bottom of the slab. Figure 4 shows the temperatures at the top and bottom of the slab during a typical 90 hours of the test. One
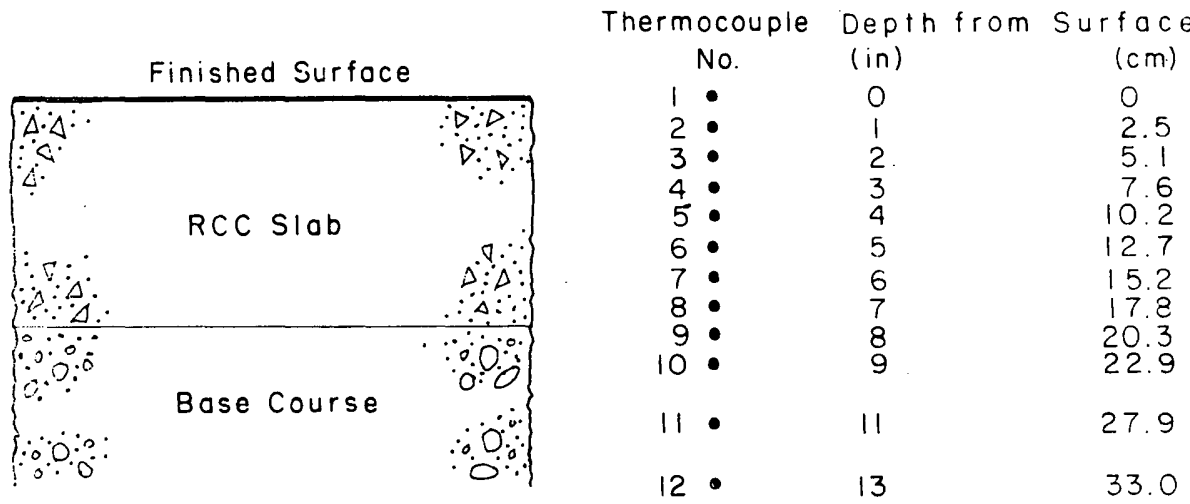

Figure 2. Typical set of thermocouples.

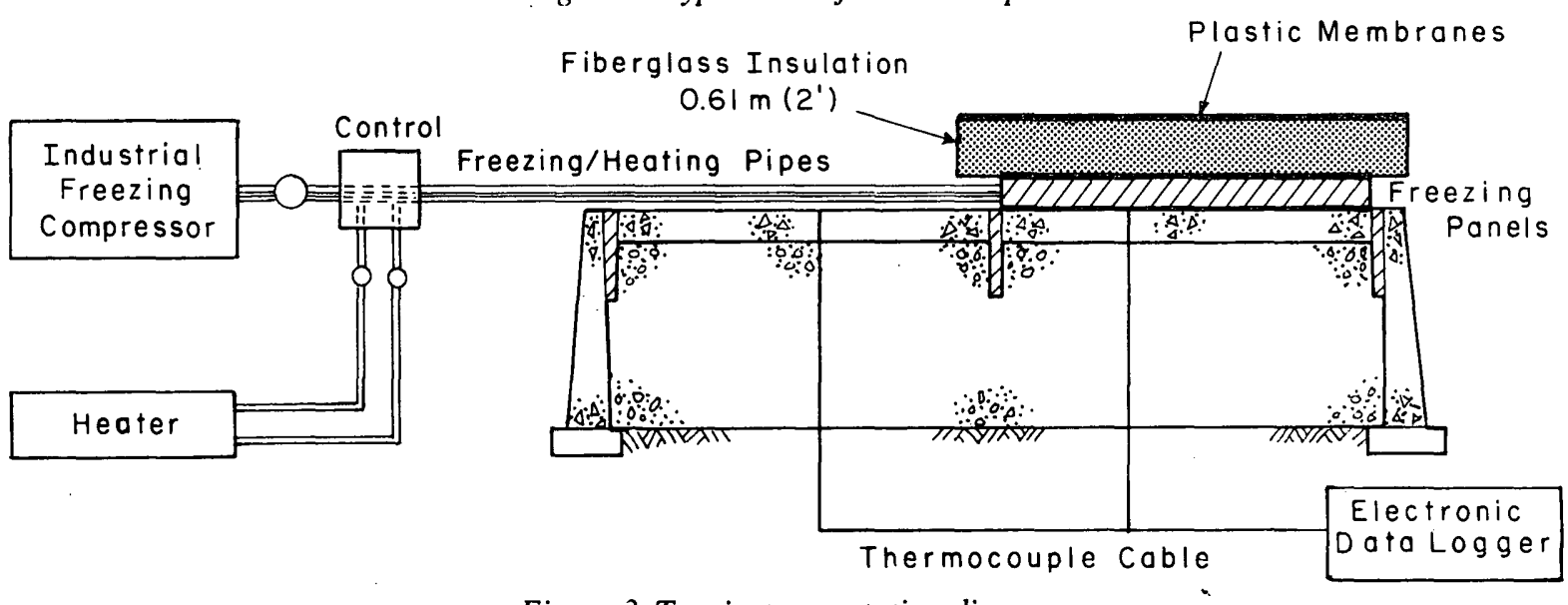

Figure 3. Test instrumentation diagram. 


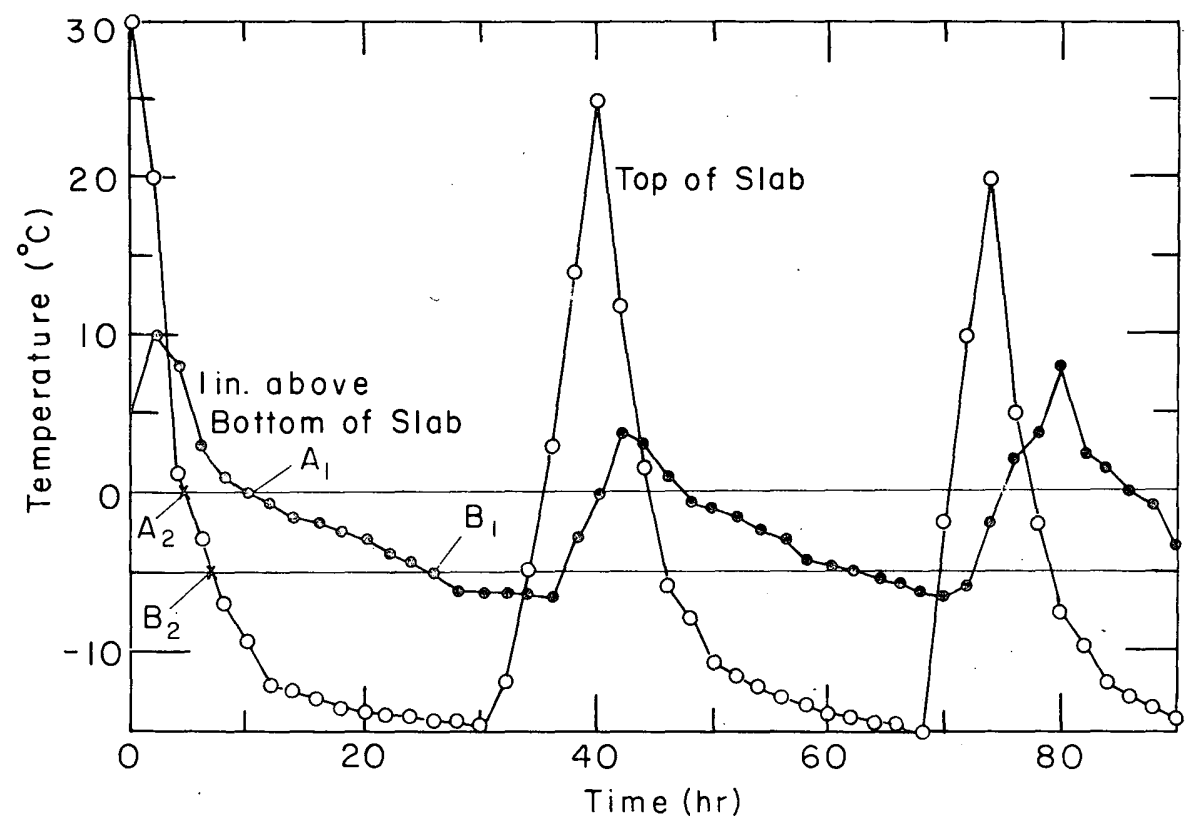

Figure 4. Temperature of the slab during 90 hours. The points $\mathrm{A}_{1}, \mathrm{~A}_{2}, \mathrm{~B}_{1}$ and $\mathrm{B}_{2}$ are used to calculate the average cooling rate as shown in Table 4.

Table 4. Average rate of cooling.

\begin{tabular}{llll} 
Level & Line & \multicolumn{2}{c}{$\begin{array}{c}\text { Average } \\
\text { rate of cooling }\end{array}$} \\
\hline of/hour & ${ }^{\circ}$ C/hour \\
\hline Bottom of slab & $\mathrm{A}_{1}-\mathrm{B}_{1}$ & 0.41 & 0.23 \\
Top of slab & $\mathrm{A}_{2}-\mathrm{B}_{2}$ & 3.75 & 2.08 \\
\hline
\end{tabular}

freeze-thaw cycle took an average of 40 hours. The average cooling rate from $0^{\circ} \mathrm{C}\left(32^{\circ} \mathrm{F}\right)$ to $-6.67^{\circ} \mathrm{C}\left(20^{\circ} \mathrm{F}\right)$ is given in Table 4.

\section{Sampling and testing}

The freeze-thaw test was interrupted for inspection of the surface, sampling and testing after 7, 15, 45, 200, 250 and 300 cycles. Three cores were taken from each test section at each interruption. The holes were patched with PCC, and a 7.6- $\mathrm{cm}(3-\mathrm{in}$.) head of water was placed over the pavement for three days. The head of water was then removed, leaving the surface wet. The freezingheating system was reinstalled, and the test was continued for a total of 300 cycles.

Additionally three beams were taken from each test section after 200 cycles. They were used for a second test of rapid freeze-thaw cycles. At 200 cycles it became apparent that a large number of freeze-thaw cycles would be needed to produce noticeable damage. It was also obvious that lane B would last even longer because of its good drainage. Lane B was therefore dropped from the test. The head of water was kept over lane A for 100 days, instead of the 3 days at other stops; to create a moisture condition comparable with the worst field condition possible.

Pulse velocities, densities, splitting tensile strengths and compressive strengths were measured at each interruption. Also, the Corps of Engineers Waterways Experiment Station (WES) conducted a series of tests on samples from the test sections:

- Microscopical determination of air-void content and parameters of the air-void system in hardened concrete (ASTM C-457).

- Resistance of concrete to rapid freezing and thawing (ASTM C-666).

- Critical dilation on concrete specimens subjected to freezing (ASTM C-671).

The third test was performed for seven cycles, but critical dilation was not reached.

\section{ANALYSIS AND DISCUSSION OF THE TEST RESULTS}

\section{Overview}

The initial sampling and testing established the material condition of the test sections prior to any freezethaw cycling. The sampling and testing at other stages allowed us to monitor any change in the material properties caused by freezing and thawing. The destructive mechanism of a freeze-thaw cycle on concrete materials depends on temperature and degree of saturation.

The number of freeze-thaw cycles in pavements is 
commonly overestimated when the calculations are based on air temperature data and the freezing point for pure water at atmospheric pressure. The standard height of air temperature sensors is $1.37 \mathrm{~m}(4.5 \mathrm{ft})$ above the ground level (U.S. Army/U.S. Air Force 1985). The air temperature varies as a function of the distance to the ground level, since the earth attenuates changes in temperature. The number of freeze-thaw cycles at the pavement surface is therefore substantially smaller than that of the standard air temperature. The number of freezethaw cycles decreases as the depth into the pavement increases.

Pure water at atmospheric pressure freezes at $0^{\circ} \mathrm{C}$ $\left(32^{\circ} \mathrm{F}\right)$. The moisture in portland cement concrete is really a solution of dissolved alkalis from the products of hydration with the water absorbed from its vicinity. The size of the voids where water exists in concrete has an effect on the surface tension and consequently on the pressure to which this solution is subjected. Capillary moisture was found to freeze at approximately $-5^{\circ} \mathrm{C}$ $\left(23^{\circ} \mathrm{F}\right)($ Neville 1981). Therefore, a freeze-thaw cycle in the RCC pavement occurs when the temperature falls below $-5^{\circ} \mathrm{C}$ and then goes above $0^{\circ} \mathrm{C}$.

Normal ambient temperatures do not cause any direct damage to dry concrete. If more than $91.7 \%$ of the volume of the concrete voids is filled with water, the concrete is considered to be critically saturated. When water freezes, its volume increases by approximately

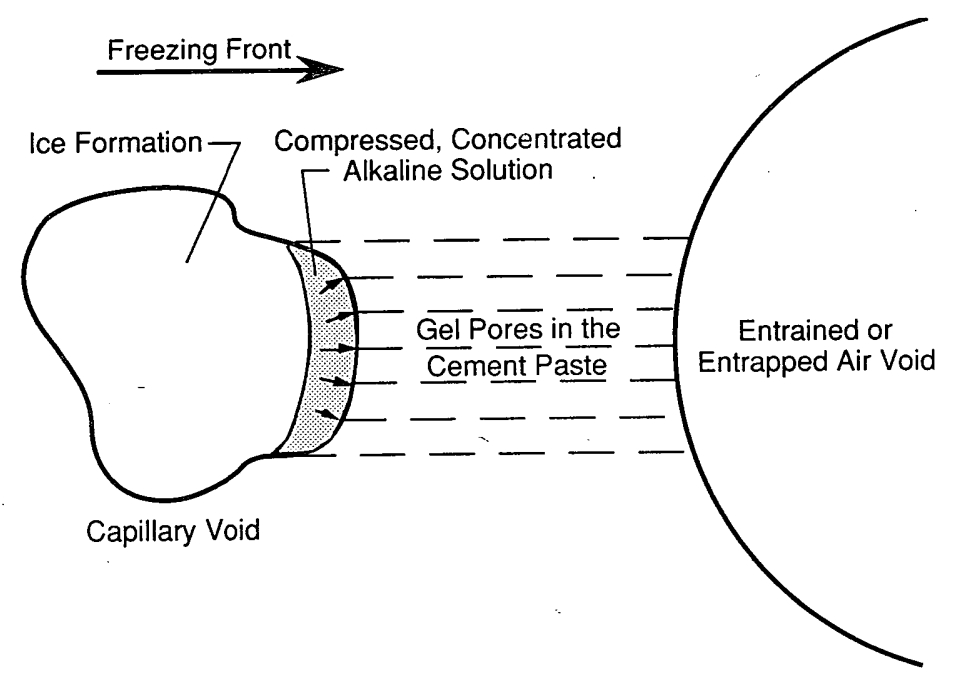

Figure-5. Generation of hydraulic pressure in cement paste.

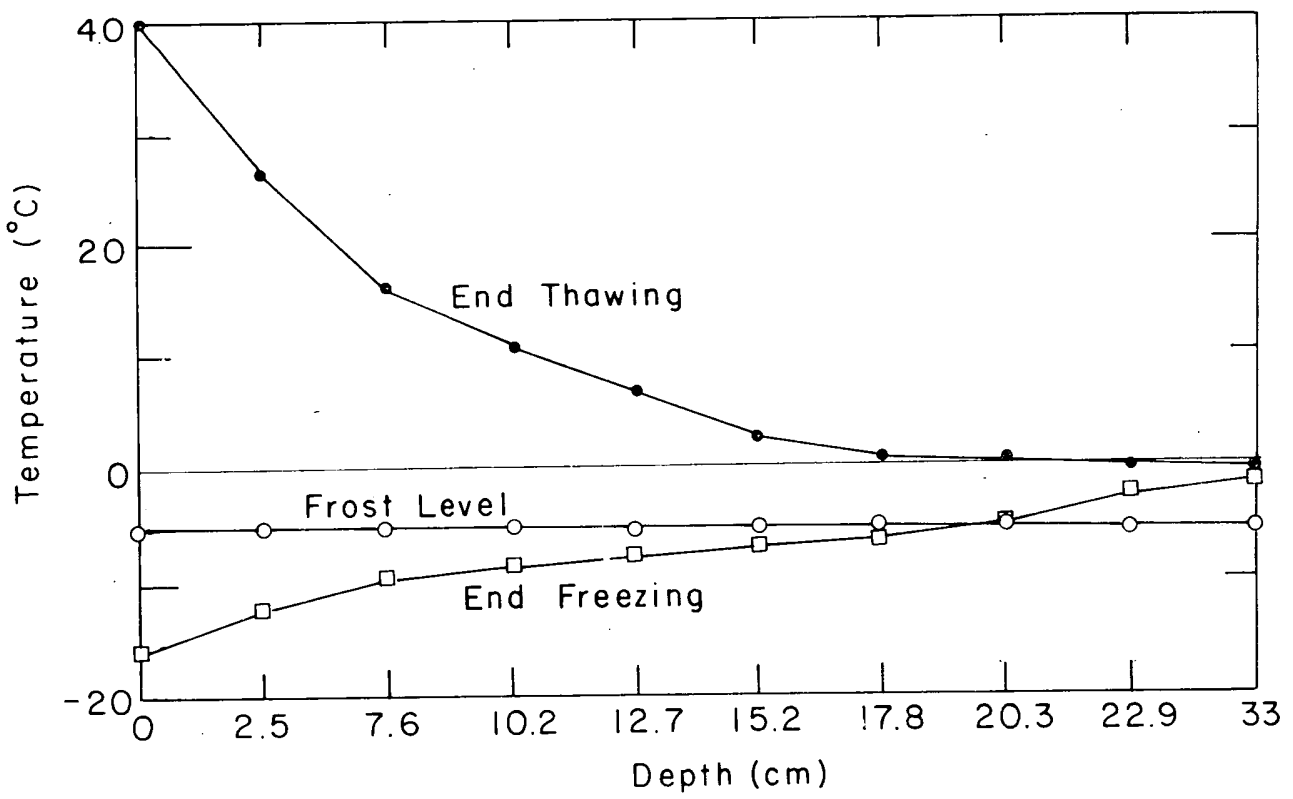

Figure 6. Temperatur' profiles at cycle limits. 


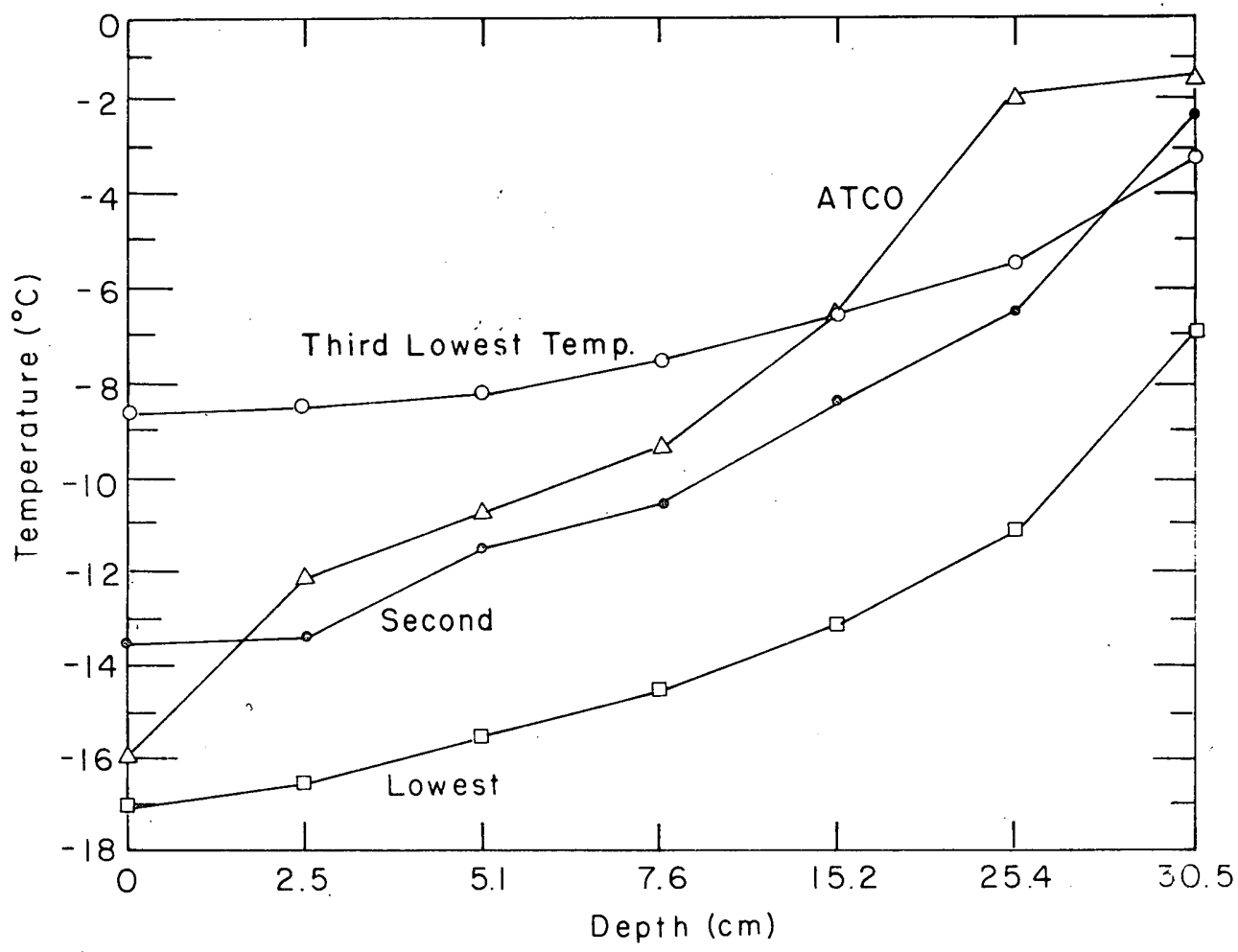

Figure 7. Peak temperature profile.

$9 \%$. When the water in the capillary cavities begins to freeze, and the combined volume of water and ice exceeds the capacity of the cavity, hydraulic pressure builds up (Fig. 5). This pressure pushes the excess water through smaller pores called gel pores. Gel pores are too small for water to freeze in them at temperatures above $-78^{\circ} \mathrm{C}$. The pressurized, supercooled water travels through the gel pores until it reaches a larger void to release its pressure. This hydraulic pressure is a function of the square of the distance between the freezing capillary void and the release void, and the temperature gradient (rate of freezing) (Cordon 1966). The spacing factor $L$ is an indicator of this distance. When the hydraulic pressure in concrete exceeds its tensile strength, internal breakdown occurs.

Figure 6 shows typical temperature profiles at the end of the freezing subcycle and at the end of the thawing subcycle. The horizontal line at $0^{\circ} \mathrm{C}$ represents the freezing point of pure water under normal conditions. The horizontal line at $-5^{\circ} \mathrm{C}$ shows the freezing point of the capillary moisture in accordance with Neville (1981). Figure 7 compares the lowest pavement temperatures during this laboratory (ATCO) test vs the three lowest PCC pavement temperatures during the 1988-89 winter at Fort Drum, New York. The laboratory temperatures were comparable with actual field temperatures in the northern United States.
Critical saturation of the RCC pavement was attempted by putting a 3 -in. head of water on the surface for 100 days. The lack of reliable methods for measuring the water content in hardened concrete prevented the exact verification of this condition. However, the long ponding of the pavement surface, and the impervious membrane placed underneath the slab, created a moisture condition far more severe than any conceivable field condition.

\section{Pulse velocity}

The pulse velocity test (ASTM C-597) was conducted at each stage to detect changes in the properties of the RCC. It is used to indicate the presence of voids and cracks. The velocity $V$ of a sonic-type wave (Whitehur 1966) is a function of the modulus of elasticity $E$ and the density of the medium $p$ :

$$
V=\sqrt{E / \rho} .
$$

A change in the pulse velocity may indicate a change in the modulus of elasticity or material density. Voids and cracks in the concrete may also be detected by the pulse velocity method. Free water in the concrete may cause misleading results and therefore must be carefully controlled. ASTM C-642, paragraph 5.1, specifies a method for obtaining a constant-weight dry condition as a reference moisture condition. 


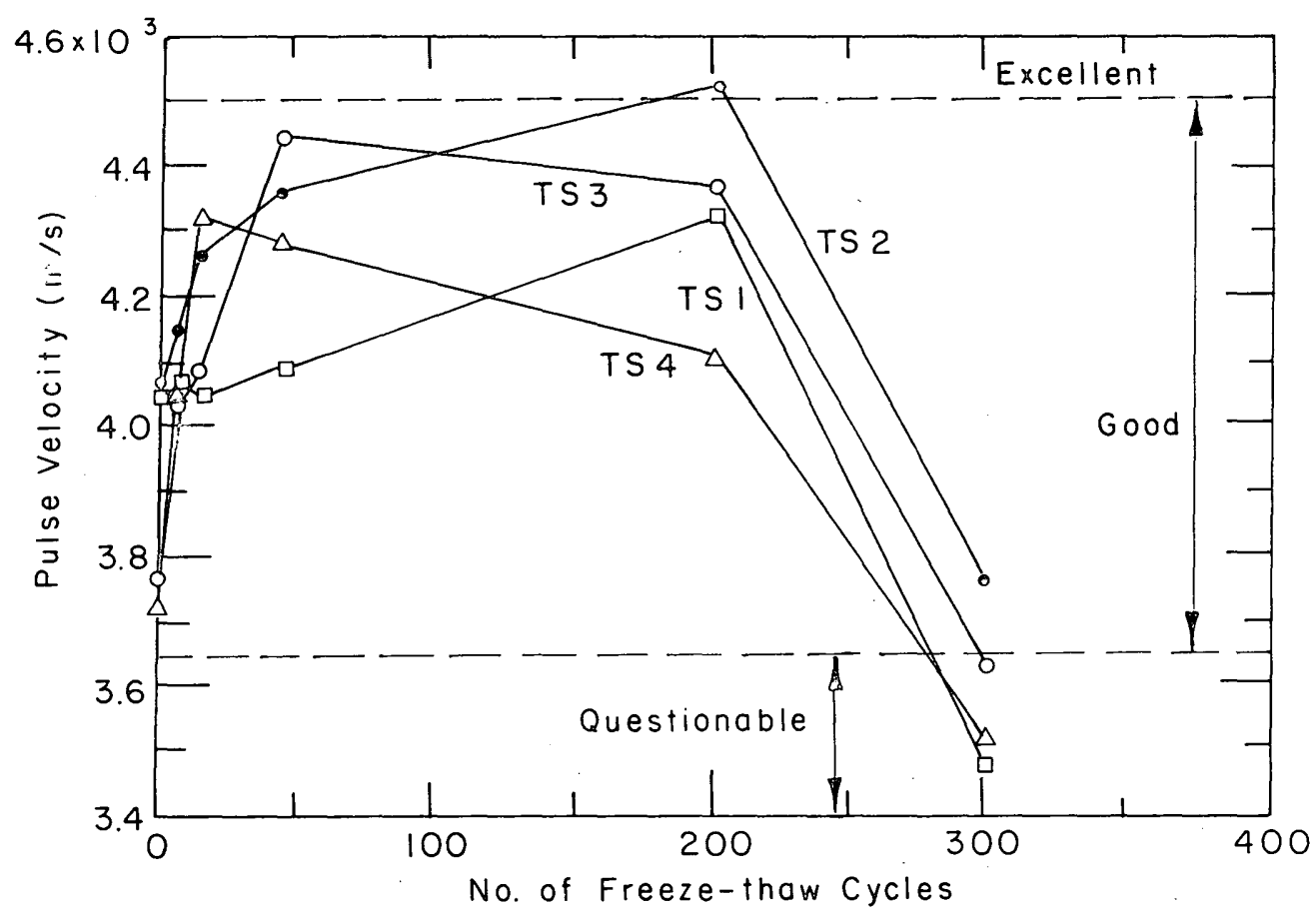

Figure 8. Pulse velocity results of the RCC CRREL test.

Leslie and Cheesman (1949) suggested the rating of concrete material shown in Table 5 based on pulse velocity measurements. In accordance with the above criteria, all the test sections are good during most of the test (Fig. 8). The pulse velocity increased during the early stages and then decreased in the later stages. The decrease may be due to internal distress (microcracking or void growth) due to frost action. This result alone is not sufficient evidence of internal distress, because of the relationship between pulse velocity and water content.

\section{Density}

Density is a measure of the quantity of mass contained in a given volume. The solid particles of the concrete material are denser (with a specific gravity of approximately 2.35 ) than water (with a specific gravity of 1.00) and air (with a specific gravity that is negligible). An increase in dry density may indicate that more water molecules have been chemically bonded during the hydration process. The density normally increases during hydration of portland cement concrete. Consequently the volume of voids decreases. The rate of hydration is initially high and gradually decreases (Winter and Nilson 1977). The ratio of the compressive strength at several stages to the compressive strength at 28 days of age is one indirect way to observe the hydration process. Figure 9 illustrates this ratio during a period of five years.

The density at zero freeze-thaw cycles shown in Figure 10 corresponds to 35 days of age, as shown in
Table 5. Rating of concrete material based on pulse velocity. (After Leslie and Cheesman 1949.)

\begin{tabular}{ll}
$\begin{array}{c}\text { Pulse } \\
\text { velocity } \\
(\mathrm{m} / \mathrm{s})\end{array}$ & \multicolumn{1}{c}{$\begin{array}{c}\text { General } \\
\text { condition }\end{array}$} \\
\hline $\begin{array}{l}\text { Above 4500 } \\
3650-4500\end{array}$ & $\begin{array}{l}\text { Excellent } \\
\text { Good } \\
21000-3650\end{array}$ \\
Questionable \\
Below 2100 & Poor \\
\hline
\end{tabular}

Table 6. Age of RCC samples at various freezethaw cycles.

Cycle Age of no. sample

035 days

762 days

153.5 months

4511 months

2002 years

$250 \quad 3.5$ years

$300 \quad 4.3$ years

Table 6. At that stage the rate of hydration is expected to be substantially reduced. The densities of all four sections appear to be approximately constant from 15 to 200 cycles (Fig. 10). By 300 cycles an important decrease in the densities is shown in test sections 2, 3 and 4. This loss of density is consistent with the reduction of the pulse velocity as reported in Figure 8 . The loss of density in test section 1 by the 300th cycle was substantially smaller, contrasting with the large reduction of its pulse velocity. The reason for this contrast is not obvious.

Although an air-entraining agent (AEA) was mixed into test section 2, it was the densest one. It appears that the improved workability given by the AEA resulted in 


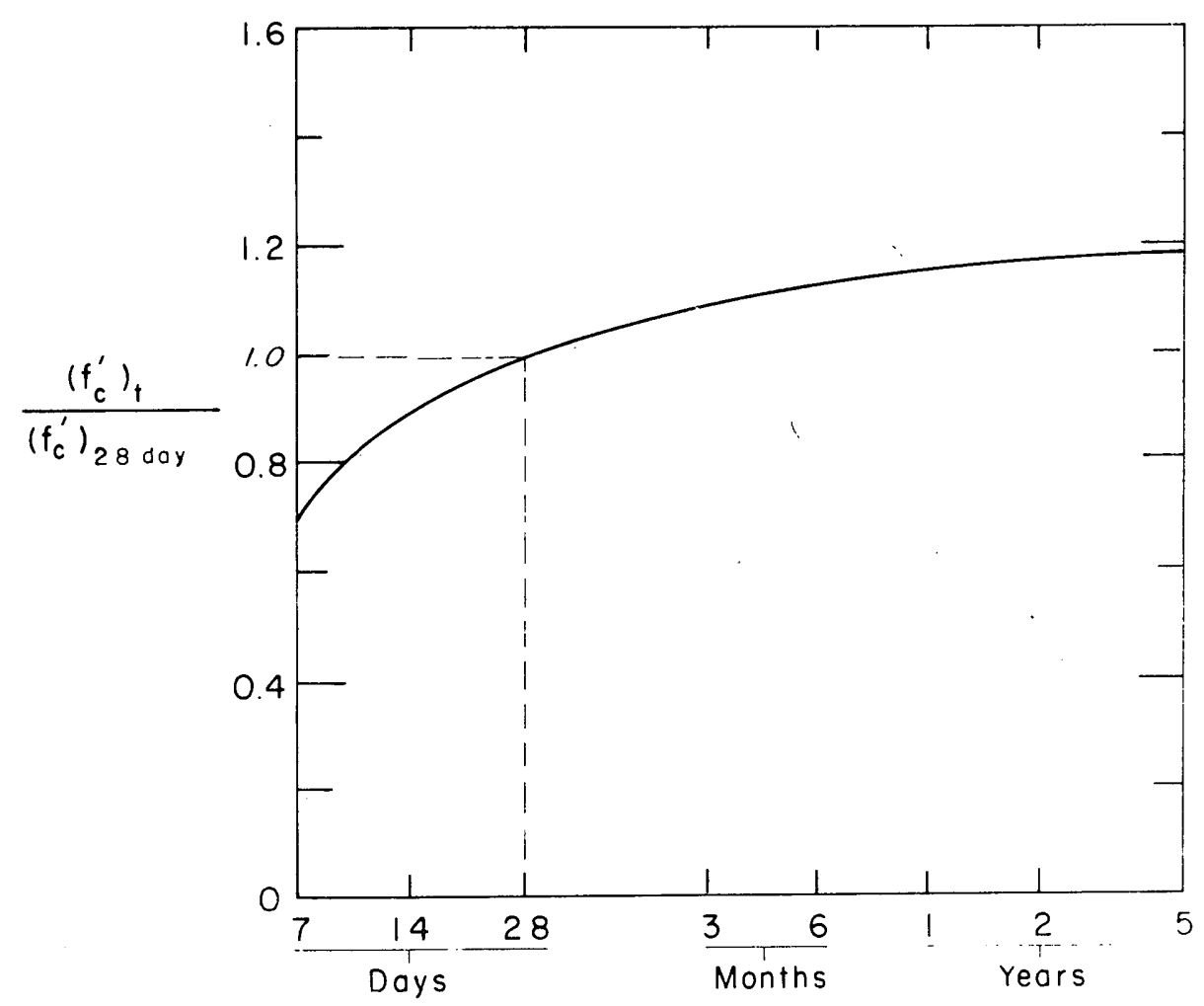

Figure 9. Effect of aging on the compressive strength. The ratio $\left(\mathrm{f}_{c}\right) \mathrm{t} /\left(\mathrm{f}_{c}\right)_{28 d a y}$ compares the compressive strength of a concrete sample at time $t$ with the compressive strength of the sample at 28 days of age. (After Winter and Nilson 1977.)

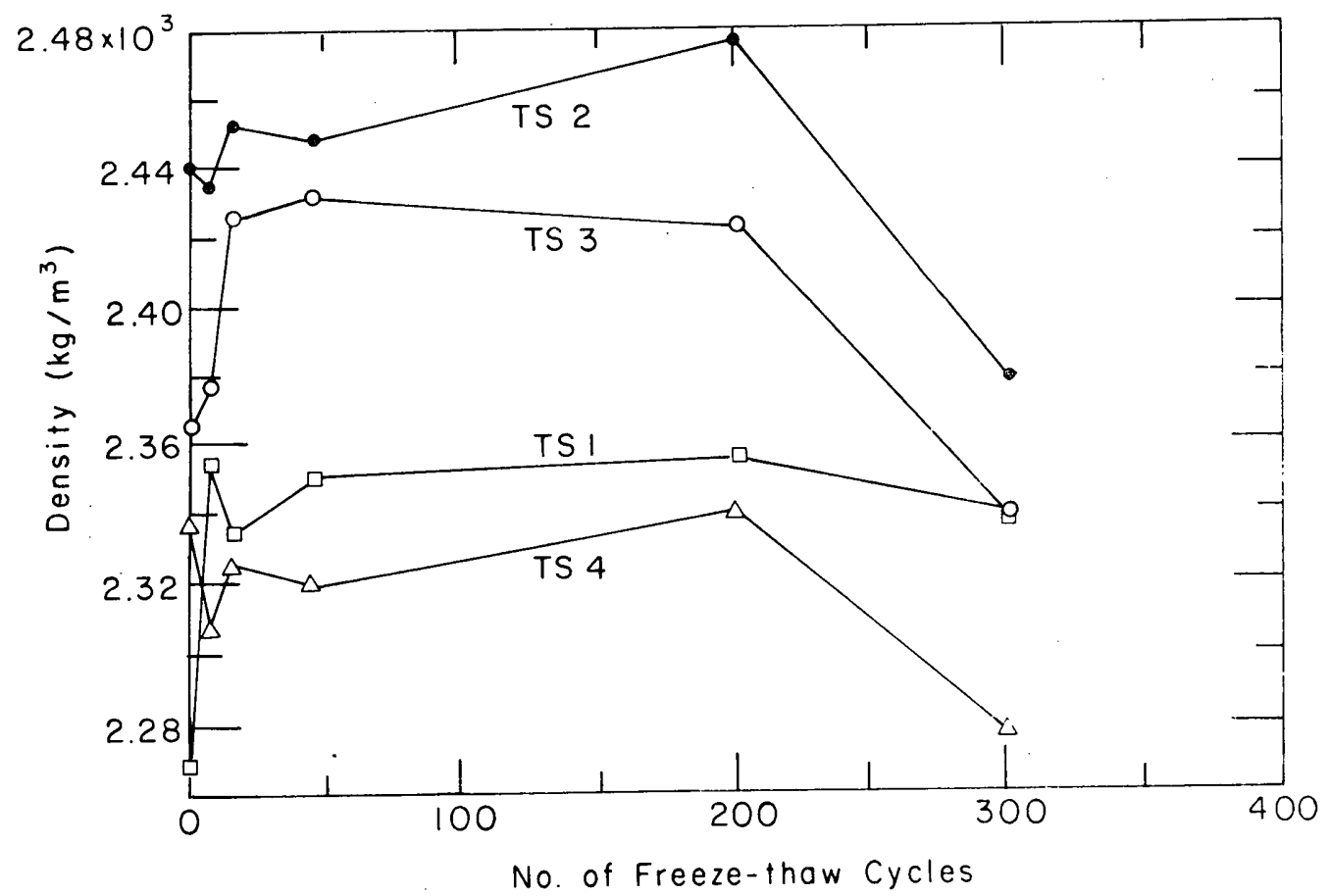

Figure 10. Density results of the RCC CRREL test. 


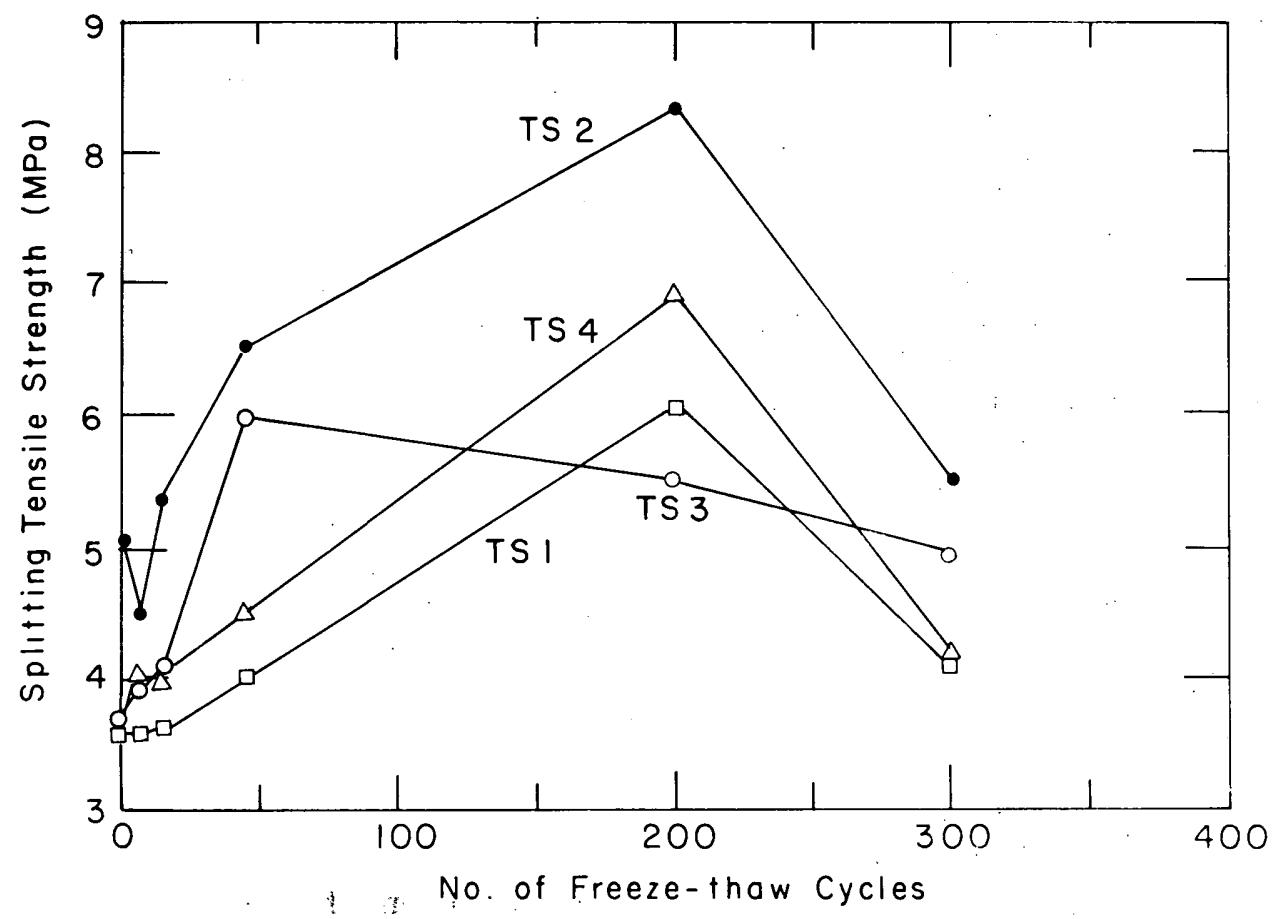

Figure 11. Splitting tensile strength results of the RCC CRREL test.

better interlock of the aggregate particles and a more eficient distribution of the cement paste. This may be the reason for the consistent superiority of test section 2 .

\section{Splitting tensile strength}

The splitting tensile strength test (ASTM C-496) measures the lateral tensile strength that occurs when a solid sample is subjected to a compressive force. Although a compressive force is applied, the measured property is the tensile strength.

All test sections followed a common pattern (Fig. 11). The splitting tensile strength of test section 3 at the 200th cycle is an exception. The reason for this exceptional value is not understood. The drop in the splitting tensile strength at 300 cycles agrees with the drop in the pulse velocities and densities at the same stage.

\section{Compressive strength}

The compressive strength test (ASTM C-39) is one of the simplest, best known and most reliable tests for assessing the overall structural condition of a heterogeneous material. The values obtained depend on the age of the concrete sample, among other factors. The 28-day test result is commonly used for thickness design of rigid pavements for streets and highways. The 90-day strength is used for the design of airfields (Packard 1984) or when fly ash is substituted for some of the portland cement. Because of the limited size of the test sections and the uncertainty of the number of cycles that would be needed, the number of cores and beams was limited. Each point in the graph represents the average strength of from one to three samples. Some dispersion of the strength values is normal.

None of the test sections experienced steady loss of compressive strength during the 300 cycles. Two of the individual values for test section 4 (the control section with 5-in.-slump portland cement concrete) fell below the initial strength, but its strength at the end of the 300 cycles was clearly larger than the strength at zero cycles. This dispersion could be controlled by increasing the number of core samples. The mix was designed to produce a minimum compressive strength of $20.7 \mathrm{MPa}$ (3000 psi). This minimum value was achieved and maintained in all the sections throughout the test. Test section 2, once again, was superior.

\section{Microscopical examination}

The microscopical determination of the air-void content and parameters of the air-void system in hardened concrete (ASTM C-457) is performed by means of a stereoscopic microscope. Two methods are commonly used: the modified point-count method and the linear traverse (Rosiwal) method. The modified pointcount method determines the total percentage of air voids. The linear traverse method measures and classifies the voids by size. It also determines the space factor $L$. ASTM C- 125 classifies the air voids in concrete into two categories based on the diameter or the width. Voids smaller than $1.0 \mathrm{~mm}(0.04 \mathrm{in}$.) are considered to be entrained air. Voids equal to or larger than that size 
are considered to be entrapped air. The spacing factor $L$ is an indicator of the maximum distance between the boundary of one void and the boundary of the nearest void. Larger $L$ values result in larger internal stresses caused by hydraulic pressures when freezing occurs.

Table 7 displays the percentage of entrained air, the percentage of entrapped air, and the total percentage of air voids. Since test section 2 contains an air-entraining agent (AEA), it has the largest percent of entrained air. However, it also has the largest percent of entrapped air. The spacing factors in Table 7 appear to disagree with the percent of air voids. The reason is not understood.

\section{Rapid freeze-thaw test}

The durability factor $D F$ is a function of the dynamic modulus of elasticity at the end of the test divided by the dynamic modulus of elasticity at zero cycles, i.e. the ratio of decay of the dynamic Young's modulus during the rapid freeze-thaw test (ASTM C-666). A value smaller than 40 is considered unsatisfactory, values between 40 and 60 indicate doubtful performance, and values over 60 indicate that the specimen is probably satisfactory (Neville and Brooks 1987). The dynamic modulus of elasticity is obtained by vibrational methods (ASTM C-215).

Two sets of rapid freeze-thaw tests were conducted. The first was done at the Corps of Engineers Waterways Experiment Station (WES). The specimens were taken at zero freeze-thaw cycles. It was a standard ASTM C666 test, procedure A. Procedure A (with freezing and
Table 7. Entrained and entrapped air, spacing factor and durability factor at 300 cycles.

\begin{tabular}{|c|c|c|c|c|c|}
\hline \multirow[b]{3}{*}{ Sample } & \multirow{2}{*}{\multicolumn{3}{|c|}{ Air content (\%) }} & \multirow{3}{*}{$\begin{array}{c}\text { Spacing } \\
\text { factor } \\
\mathrm{L} \\
(\mathrm{mm})\end{array}$} & \multirow{3}{*}{$\begin{array}{c}\text { Durability } \\
\text { factor } \\
\text { DF }\end{array}$} \\
\hline & & & & & \\
\hline & $<l m m$ & $\geq 1 \mathrm{~mm}$ & Total & & \\
\hline IA\&IB & 2.3 & 3.2 & 5.5 & 0.203 & 89 \\
\hline $2 A \& 2 B$ & 3.6 & 5.0 & 8.6 & 0.254 & 54 \\
\hline $3 A \& 3 B$ & 2.9 & 2.3 & 5.2 & 0.254 & 80 \\
\hline $4 A \& 4 B$ & - & - & - & - & - \\
\hline
\end{tabular}

thawing taking place in water) is several times more severe than procedure B (with freezing in air and thawing in water) (Neville 1981).

The results are displayed in Table 7. They disagree with the results of other tests. The second set of rapid freeze-thaw tests was conducted at the Corps of Engineers South Atlantic Division Laboratory. These were a modified version of the ASTM C-666 test, procedure A. These were the modifications:

- The specimens were subjected to 200 cycles within a full-scale test section before subjecting them to the rapid freeze-thaw test.

- The age of the concrete samples was three years as opposed to the usual 14 days.

- The concrete samples were kept immersed in water for 100 days immediately prior to the beginning of the rapid cycles.

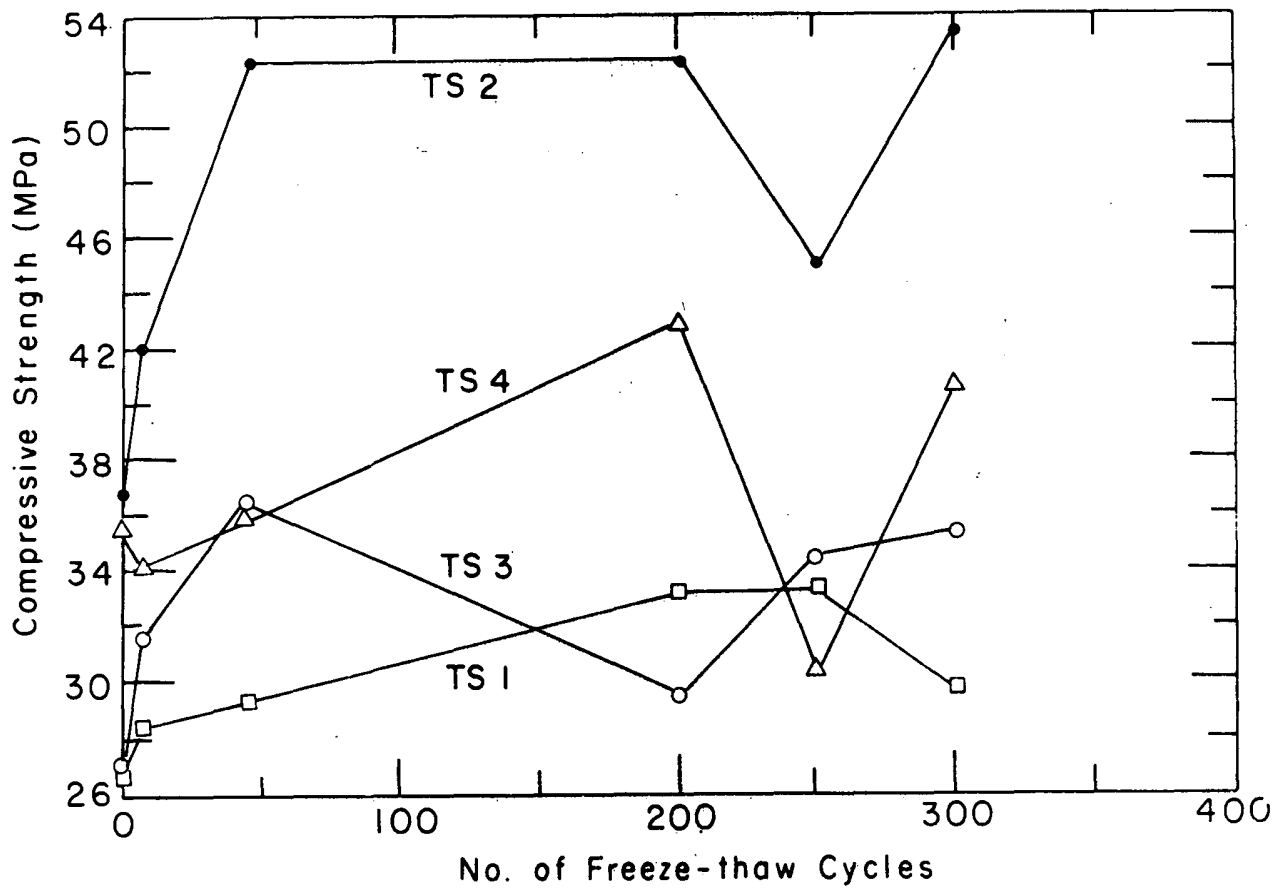

Figure 12. Compressive strength results of the RCC CRREL test. 
- The tests were continued for 600 cycles or the number of cycles needed to reduce the dynamic modulus of elasticity to $50 \%$ of its value at the beginning of the rapid freeze-thaw test. The standard ASTM test calls for 300 cycles or $60 \%$ of the dynamic Young's modulus.

The test results are presented in Figure 13. The modifications to the standard test must be kept in mind when interpreting these results. The freeze-thaw resistance should not be judged based solely on these figures. The test gives only an indication of the relative frost susceptibility of the four test sections. Figure 14 shows that test section 3 is by far the most frost susceptible. Similarly, it appears that test section 2 is the most frost resistant. This agrees with the result of Figures 8-12.

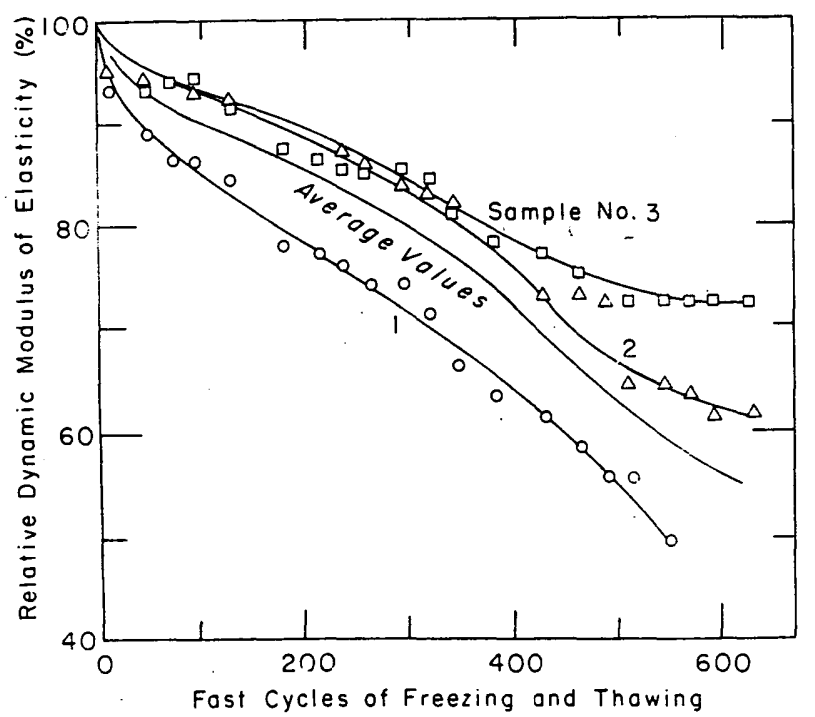

a. Test section l.

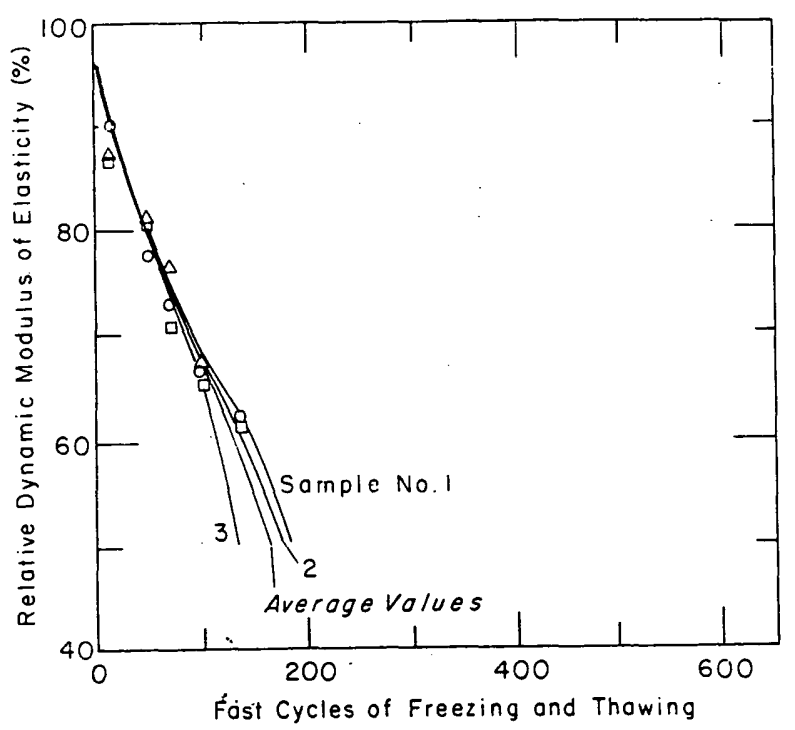

c. Test section 3.

\section{Relative overall performance}

The relative frost susceptibility of test section 3 suggested by the second rapid freeze-thaw test is only moderately supported by the splitting tensile strength and compressive strength test results. However, the superiority of test section 2 was clearly revealed by all tests, except the first rapid freeze-thaw test. The measurable difference between the performance of test section 2 and test section 3 is particularly interesting because their ingredients were identical in quantity and quality except that test section 2 included an air-entraining agent. Table 7 confirms that some entrained air was generated in section 2, but some additional entrapped air was also introduced.

Test section 1 was made with cement and water con-

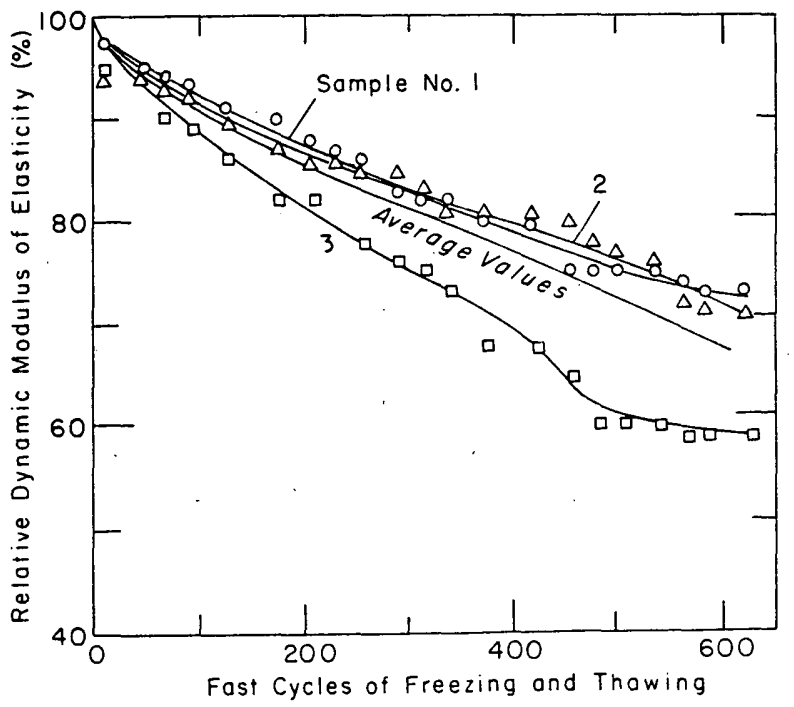

b. Test section 2 .

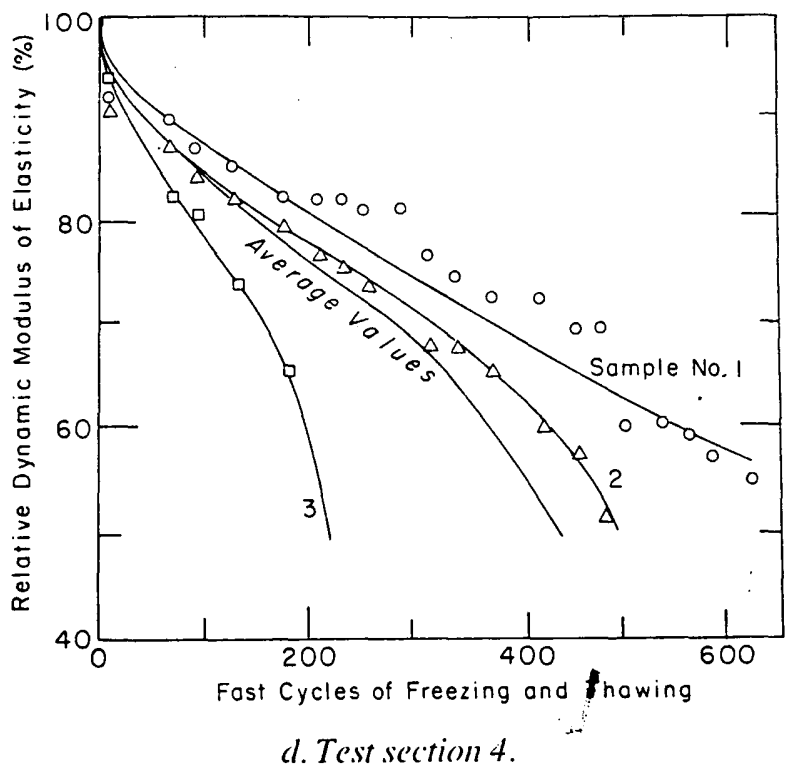

Figure 13. Rapid fice-e-thaw test results. 


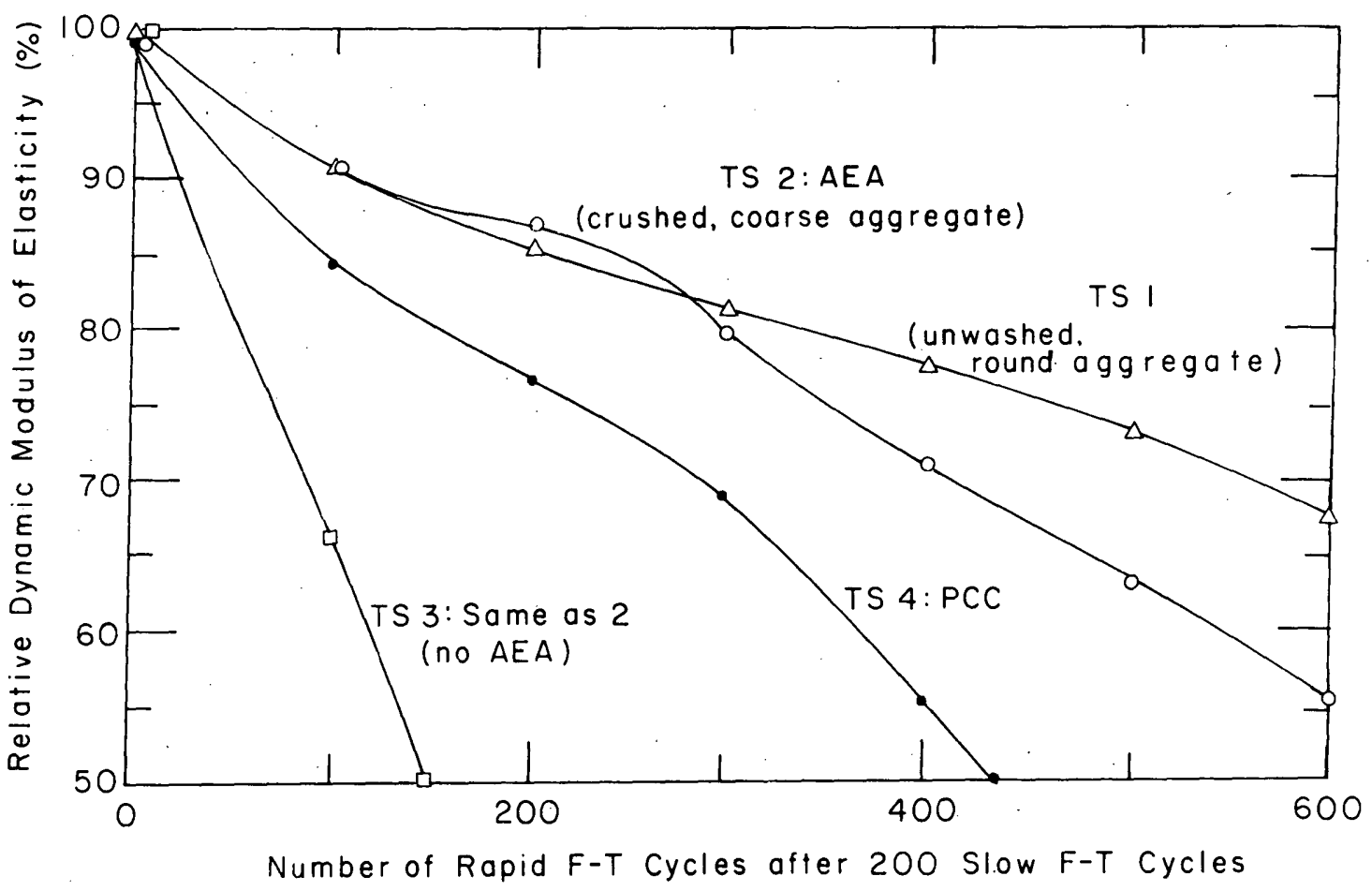

Figure 14. Averuge decay of the dynamic modulus of elastic ity for the four test sections. The 100\% modulus of elasticity was at 200 slow ficeze-thaw cycles, prior to any rapid fiece-thaw cycles.

tents similar to sections 2 and 3 , but its aggregate was natural, uncrushed and unwashed. Although it contained more fine particles, its density was found to be relatively low, as shown in Figure 10.

Test section 4 was the control section made of readymixed concrete. It was constructed with conventional methods, and it contained an air-entraining agent. Its splitting tensile strength and compressive strength decayed after 200 cycles. Its density was the lowest, probably because of the high water-cement ratio $(0.70)$. The permeability of a PCC material made with a ratio of 0.70 is on the order of 100 times that of a similar PCC made with a water-cement ratio of 0.35 (Neville 1971). RCC is denser than PCC for identical mixes because of its lower water-cement ratio and because of aggregate interlock due to the heavy compaction.

The overall relative performance of the four test sections, in order from best to worst, was test section 2, test section 1, test section 4 and test section 3 .

\section{Severity of test vs field conditions}

Important differences between the degree of severity of the laboratory tests and the probable field conditions must be considered. This test program was not intended to duplicate field conditions. The ponding of the pavement for several days at various stages of the test, the impervious membrane placed in the base course to hold water, and the extreme 100 -day ponding at 200 cycles undoubtedly produced more moisture exposure than found at any field pavement. Moreover, the second rapid freeze-thaw test included total immersion of small specimens during a period of time parallel with the ponding of the test sections. This means that water entered the samples through six surfaces, whereas in an actual field pavement, water enters into the concrete only through the top surface (rain and air moisture) and the bottom surface (ground water). The supply of water in field pavements is limited by the length of rainstorms, evaporation, and surface and subsurface drainage.

The rate of cooling is the second major factor. The faster the cooling, the higher the hydraulic pressure developed inside the capillaries in the concrete (Cordon 1966). The rate of cooling on the full-scale test section (Table 4) was higher than that occurring in nature, and the rate of cooling on the rapid freeze-thaw tests is far above any rate of cooling found in real field projects.

With these considerations in perspective, even test section 3 , which revealed some frost susceptibility, may have performed satisfactorily in a field project during the life expectancy of the pavement.

\section{Failure criteria}

The average 28 -day compressive strength value is commonly used for designing portland cement concrete structures. In this experiment the sampling and testing at zero cycles took place when the test sections were 35 
days old. Normally the compressive strength increases with the time, following an asymptotic pattern (Fig. 9). The compressive strength test is one of the simplest, best known and most reliable means of assessing the structural integrity of a concrete specimen.

Therefore, the following failure criterion is suggested: An RCC specimen is considered to have failed when its compressive strength falls consistently below its 28-day compressive strength.

\section{CONCLUSIONS}

The fundamental objective of this experiment was to evaluate the durability of roller-compacted concrete subjected to cycles of freezing and thawing. At the end of the 300-cycle, full-scale freeze- thaw test, none of the test sections failed. Tayajbi and Okamoto (1987) established that the overall engineering properties of RCC are similar to those of conventional concrete.

This study shows that $R C C$ is a suitable construction material for pavements in cold regions and may be used as an alternative to conventional portland cement or asphalt concrete. Entrained air, though beneficial, did little to improve the performance of RCC.

This experiment alone does not provide an estimate of the life expectancy of an RCC pavement under field conditions. An ongoing research program at CRREL will provide extensive environmental data relating to the main variables affecting the durability of RCC pavements. With the results of this experiment and the field data, a method for estimating the life expectancy of RCC pavements may be developed.

Further studies relating the material properties, field performance and this experiment would enhance our knowledge of the variables that affect the durability of RCC pavements. This knowledge could then be transformed into practical improvements of design and construction methods.

\section{LITERATURE CITED}

Cordon, W.A. (1966) Freezing and Thawing of Concrete Mechanisms and Control. American Concrete Institute and the Iowa State University Press.

Gardner, C.R. and R.A. Eaton (1984) Roller compacted concrete test section construction at USA CRREL. USA Cold Regions Research and Engineering Laboratory, Internal Report 874 (unpublished).

Gillespie, H.M. (1989) Nations try concrete overlays. Roads \& Bridges, February, p. 16.

Leslie, J.R. and W.J. Cheesman (1949) An ultrasonic method of studying deterioration and cracking in concrete structures, American Concrete Institute.

Neville, A.M. (1971) Hardened Concrete: Physical and Mechanical Aspects. American Concrete Institute and the Iowa State University Press.

Neville, A.M. (1981) Properties of Concrete. London: Longman Scientific and Technical.

Neville, A.M. and J.J. Brooks (1987) Concrete Technology. London: Longman Scientific and Technical.

Packard, R.G. (1984) Thickness design for concrete highway and street pavements. Portland Cement Association.

Tayabji, S.D. and P.A. Okamoto (1987) Engineering properties of roller-compacted concrete. Transportation Research Board, Washington, D.C.

U.S. Army/U.S. Air Force (1985) Pavement design for seasonal frost conditions. Chapter 4 in US Army/Air Force, Technical Manual 5-818-2, p. 1-2,

White, T.D. (1986) Mix design, thickness design, and construction of roller-compacted concrete. Transportation Research Record, 1062: 2. Transportation Research Board, National Research Council, Washington, D.C.

Whitehur, E.A. (1966) Evaluation of concrete properties from sonic tests. American Concrete Institute and the Iowa State University Press, p. 3 and 69.

Winter, G. and A.H. Nilson (1977) Design of Concrete Structures. New York: McGraw-Hill, Inc. 
